\title{
Balochistan: News coverage in national and local newspapers \\ (A comparative study of selected newspapers)
}

\author{
Babrak Niaz $^{1,}$ Prof.Dr. Seemi Naghmana Tahir ${ }^{2}$ \\ Faheem Baloch ${ }^{3}$, Sadaf Irtaza ${ }^{4}$
}

\begin{abstract}
This paper attempts to compare three leading newspapers to cover the news contents related to Balochistan. Balochistan is largest province geographically but it is given less coverage on electronic and print media. There is undeclared war like situation in Balochistan and due to many conflicting issues the region is declared as conflict zone. The ethnic unrest and sectarian rifts have been escalated in the last few years and it is very challenging to practice journalistic activities. The issues related to Balochistan cannot be resolved until it is given proper coverage in both medium. The study aims to evaluate news contents of front pages of Daily Jang Quetta, Daily Express Quetta Century and Daily Intikhab Quetta. The front page of May 2017 is selected to be evaluate. To curtail the element of peril for journalists working in conflict zone and on the basis of findings from collected data suitable recommendations are proposed.
\end{abstract}

\footnotetext{
1.Assistant Professor, Media \& Journalism Department University of Balochistan.

2. Chairperson Department of Media and Journalism University of Karachi.

3.Assistant Professor, Media \& Journalism Department University of Balochistan.

4.Lecturer, Media \& Journalism Department University of Balochistan.
} 


\section{Introduction}

Balochistan is largest territory geographically and is less populated province of the country. When it comes to development, it is less developed and under privilege province. Balochistan is considered as the poorest region of the country despite full of natural resources.

The press in Balochistan started in 1888 by Parsi community after establishing Victoria press. The monthly Balochistan Advertiser was the first newspaper of Balochistan and it was started by Dada Bai Golwala in Nov 1888 (Tahir.2005). However, the regular press was started in 1938, when Khan Abdul Samad Khan Achakzai succeeded in started declaration for newspapers from Balochistan.

With the boom of electronic media in Pakistan, many news organizations started transmission from Pakistan and from Gulf states. The employees of newspapers were recruited in electronic media sector and the main aim of these news organizations remain commercial. The Balochistan and coverage related to Balochistan remain a question for both electronic and print media in Pakistan. News organizations, especially electronic media policies are manipulated by multinational companies and most of the coverage usually depends upon revenue generation. Balochistan lacks the private sector than rest of the country and media normally give less coverage to Balochistan because of the fact, Balochistan is not good source of revenue generation for media industry.

Historically, Pakistan is ruled by different political and dictatorial regimes and impacts of those reigns had negative aftermaths. Less social development, poor economical and political development has increased the grievances among local populace. These grievances increased with 
time and it turns Baloch youth and Baloch Nationalists to demand for provincial autonomy(Atarodi011).

Balochistan is witnessing another insurgency and it is believed that it is fifth insurgency in the province since inception(Grare, 2013).

The situation of media in Balochistan is worst for journalists and the region is considered to be most dangerous for journalists. Journalists are directly or indirectly intimated by different factors to not report with freedom of expressions. The issues related to Balochistan are not given proper coverage in main stream media and so far no sincere efforts on behalf of media are made to resolve the issue of Balochistan by making public opinion and by indulging conflicting parties in dialogue process. The news related to Balochistan are given coverage only, when any incident occurs. The current study evaluates the selected newspapers in overall coverage of the news contents related to Balochistan. The front page of the selected newspapers are analyzed to see that how these newspapers have given coverage to Balochistan in one month time.

\section{Brief historical background of media in Balochistan}

The daily newspapers publication are more than 190 in Balochistan and more than 150 monthly magazine are publishing from Balochistan. Most of these newspapers and magazines are published in Balochi language. However, there are many publications in Pashto and Brauhvi languages. The Quetta city is journalistic hub in Balochistan and national news organizations offices are established in Quetta city. The international news organizations offices also exists in Balochistan. But it is significant to learn that these national and international organizations working is restricted to report only. Many of the journalists in Balochistan are 
working on part time basis with news organizations. The journalist's community in Balochistan is working under the umbrella of Balochistan Union of Journalists. According to Balochistan Union of Journalists sources, " More than 500 journalists are working in Balochistan and only 140 are members are members of Quetta press club."

The Quetta press Club was established in 1959 and founding members of the club were Maulana Abdullah and Maulana Abdul Karim. Initially it was known as Quetta press club and Kalat state. There are also few organizations which works for the safety of journalists in Balochistan. These organizations include Balochistan Daily newspapers Editor Council, The Pakistan Newspapers Employees council and the press council etc.

The Pakistan Federal Union of Journalists provincial chapter is Balochistan Union of Journalists. The BUJ under the umbrella of PFUJ strives to work for the journalists community in Balochistan and it arranges different professional courses and workshops for journalists. Balochistan is considered a garrison city because of the conflicts of different nature in the province from decades. The state apparatus has strict surveillance over the contents of media and government machinery use different tactics to control the media (Sarina Singh, 2008).

The boom of electronic media in the country has also created prospects in Balochistan and the youth of Balochistan are now more optimistic. People of Balochistan are now more aware of media's role and more students are now getting admission in journalism departments of different universities to highlight the issues more professionally when they qualified.

The working conditions for journalists are not ideal for journalists in Balochistan. It was obvious for the journalists if reporting did not go for 
some body, journalists dependency was state machinery but now things are totally changed for journalists in Balochistan. The journalists fears threats from state apparatus as well.

\section{Conflict and role of media}

Media can play an important role in conflicts like situation. They can play active role in resolving the conflict by highlighting issues of conflict and giving proper and prominent coverage of those conflict. They can play another role by keeping itself out of the conflict and stay independent. What role media plays in conflicting zone and even before and after the conflict depends upon many factors.

The conflict is common phenomenon in modern world. Nations, people, organizations, institutions and relations of the states are in different phases of conflicts. By the end of cold war, the world has witnessed countless conflicts that causes deaths and displacement of the people from one region to another. According to UN reports, over the last ten years more than two million children have been died in the conflicts around the world.

(http://www.soschildrenvillages.org.uk/sos-children/childsoldiers,2017)

With the detonation in media industry and considering media as fourth pillar of the state, the media's role is crucial in addressing the conflicting issues and media can play constructive role in resolving the conflicts related to Balochistan. But it, somehow, creates sort of controversy that should media stay detached itself from the events of conflicts that occurs or should it take some stern stance and become attached to a cause, may be for the cause of peace. One of the drawback of 
such approach could be taking side to the conflicting parties. But ultimately conflict requires a solution that can be addressed by addressing the underlying problems. Peace is more than absence of war and there is danger for journalists by taking side in the conflict unintentionally. Journalists use platforms within media to present their views and opinion on editorial pages of the newspapers and they use effectively electronic media's current affairs shows for their views. That's how media sometimes becomes an active actor in conflict. The editorial position of media on certain issues of the conflict leads to the omission of other aspects (Support, 2016). Therefore, the policy makers of the news organizations need to focus on media's role . Involving societies in media and discussing issues of conflicts in such a way as to allow non violent resolution of conflict. The public spheres should have free flowing access to the information and media must have play role by enabling the audiences that they should listen to the views of ordinary citizens. As Jurgen Habermas (1992) says that "a discursive arena that is home to citizen debate, deliberation, agreement and action".

\section{Brief profile of selected newspapers in Balochistan}

\section{Daily Jang}

Jang newspaper was started by Mir Khalil Ur Rehman in the year 1939. Mir Khalil ur Rehman has the credit for bringing Muslim press to the peak in sub continent. The daily Jang was powerful voice for the Muslims of sub-continent and it was fearless supporter of the mission of all India Muslim League under the supreme leadership of Quaid-i-Azam Muhammad Ali Jinnah. During the struggle period of the last century before independence Mir Khalil ur Rehman and Jang was on front line. 
The Daily Jang has many editions and publishes from Lahore, Karachi, Rawalpindi, Quetta and London simultaneously. The Jang group is considered to have largest circulation in Pakistan. The daily Jang has the honor to use computerized Urdu calligraphy in Pakistan. The other newspapers of its time influenced from the technology of Jang and adopted many techniques from Jang newspapers. Jang group is financially strong and it pays better wages to its employees.

The daily Jang has played vital role even after the partition and always strived for the free flow of information to the masses. During the strict policy of Zia regime the Jang newspaper adopted strong stance against the authoritarian rules. The Jang newspapers role for the democracy continuation in the country is appreciate able.

\section{Daily Express Century}

The daily Express Century was started in the year 1998 and it is published by century Publications owned by Lakson group. It is simultaneously published from Islamabad, Karachi, Lahore, Peshawar, Quetta, Multan, Faisalabad, Gujranwala, Sargodha, Rahim Yar Khan and from Sukkar.

\section{Daily Intikhab Quetta}

Daily Intekhab is one of the prominent newspapers of Balochistan which started its publication from the industrial city Hub in 1989. It was published by two veteran journalists of Jang group, Mr.Anwar Sajidi and Mr. Sarkar Ahmed. The main reason behind publishing of Daily Intekhab from Hub was that there was a market vacuum in the Hub city, which is located almost at a distance of $650 \mathrm{KM}$ from the capital Quetta. In those days, owing to lack of transport facilities, the national dailies were limited to Quetta and its adjacent areas. Big newspapers did not took any interest 
in sending their newspapers into far flung areas such as Hub, Bela, Awaran , Pasni, Kech,etc. Ironically, they neglected a major portion of the population of the province.

Owing to the industrial revolution in Hub in the late 1980s, its population increased at a very rapid pace, furthermore, its proximity with areas like Makran Division and Awaran, where there was no newspaper, so a quality newspaper was the need of the hour and Intekhab rose to the occasion. It adopted a very different policy, unlike national dailies, it focused mostly on local news, but at the same time, it also gave a fair coverage to national and international news. In 1998, it started its Karachi edition and in 2003 it also its Quetta edition.In the interior Balochistan, especially in the Baloch populated districts, it is the most popular newspaper. The policy of giving more coverage to the local news also affected the policy of the national dailies. Prior to Intekhab, national newspapers give a meagre to the local issues, but to attract the local readership, they are now compelled to give a good amount of coverage to the local news. As a result,now local issues make headlines in the front page of the national dailies.

\section{Research Methodology}

"Walizer and Weiner (1978) defined content Analysis as any systematic procedure devised to examine the content of recorded information; Krip-pendorf (1980) defines it as research technique for making replicable and valid references from data to their context. Kerlinger's (2000) definition is fairly typical: Content analysis is a method of studying and analyzing communication in a systematic, objective and quantitative manner for the purpose of measuring variables." A method of 
Content Analysis was used for the comparison of newspapers. The content analyses of the following newspapers were done.

\section{Justification for the Selection of Daily Jang Quetta, Daily Express Century Quetta \& Daily Intikhab Quetta}

Four factors were kept into view before selecting the abovementioned newspapers for the study:

- Distribution or Circulation

- Influence on decision makers

- Quality of news content

The Daily Jang Newspaper was selected on the basis of its reputation and readership in Quetta city and Pakistan. Overall circulation of Daily Jang Quetta is in most part of the province and other characteristic which was kept in mind was its influence on readers. The Daily Express Century Newspaper was selected on the basis of competitor Newspaper to the Daily Jang in Quetta city. Its quality of news content, circulation and influence upon readers were kept in mind while selecting Daily Express Century for content analysis. The Daily Intikhab Quetta was selected on basis, that it is published by Local inhabitants in Quetta city, while news quality and circulation of Daily Intikhab Quetta were necessary characteristics which were kept in mind during selection.

\section{Coding Entity}

Headline of all news items on front page were taken as coding unit for identifying the topics in this particular study. Content Analysis of Front pages were made of selected newspapers. The contents analysis of

the selected newspapers were done and for this purpose May 2017 month newspapers were selected. All the contents related to Balochistan were 
analyzed. The news contents include Political, Crime news, Statements from government, news in the form of press releases and another category by the name of others is also kept and analyzed.

\section{Samples and Operational Definitions of Units of Analysis}

\begin{tabular}{|c|c|c|c|}
\hline Topic & Universe & Sample & $\begin{array}{l}\text { Unit of } \\
\text { Analysis }\end{array}$ \\
\hline $\begin{array}{l}\text { News Items } \\
\text { related to } \\
\text { Balochistan } \\
\text { on front } \\
\text { page of the } \\
\text { Selected } \\
\text { Newspapers } \\
\text { and } \\
\text { photographs } \\
\text { related to } \\
\text { Balochistan. }\end{array}$ & $\begin{array}{l}\text { All news and } \\
\text { photographs } \\
\text { related to } \\
\text { Balochistan, } \\
\text { including } \\
\text { Political and } \\
\text { non-political } \\
\text { on Front page } \\
\text { of selected } \\
\text { Newspapers } \\
\text { (Daily Jang } \\
\text { Quetta, Daily } \\
\text { Express } \\
\text { CenturyQuetta } \\
\text { and Daily } \\
\text { Intikhab } \\
\text { Quetta). }\end{array}$ & $\begin{array}{l}\text { All News } \\
\text { related to } \\
\text { Balochistan } \\
\text { on front } \\
\text { page of } \\
\text { selected } \\
\text { Newspapers } \\
\text { of May } \\
2017 \text { were } \\
\text { selected for } \\
\text { content } \\
\text { analysis. }\end{array}$ & $\begin{array}{l}\text { Each News } \\
\text { related to } \\
\text { Balochistan } \\
\text { were } \\
\text { selected and } \\
\text { the news } \\
\text { were } \\
\text { divided in } \\
\text { following } \\
\text { categories. } \\
\text { Category 1: } \\
\text { Government } \\
\text { Category 2: } \\
\text { Political } \\
\text { Category 3: } \\
\text { Crime } \\
\text { Category 4: } \\
\text { Other }\end{array}$ \\
\hline
\end{tabular}




\section{Data Presentation}

The following tables gives detail of the news contents published in Daily Jang Quetta, Daily Express Century Quetta and Daily Intikhab Quetta in the month of May 2017. The news contents are divided on the basis of its categories and on the basis of space given to the news.

\begin{tabular}{|c|c|c|c|c|c|c|}
\hline \multicolumn{7}{|c|}{ Daily Express Century May 2017} \\
\hline \multirow[t]{2}{*}{ Categories } & \multicolumn{5}{|c|}{ News Column } & \multirow[b]{2}{*}{ Total } \\
\hline & $\begin{array}{l}1 \\
\text { colu } \\
\text { mn }\end{array}$ & $\begin{array}{c}2 \\
\text { colu } \\
\text { mn }\end{array}$ & $\begin{array}{l}3 \\
\text { colu } \\
\text { mn }\end{array}$ & \multicolumn{2}{|c|}{$\begin{array}{l}4 \\
\text { colum } \\
\text { n }\end{array}$} & \\
\hline Category 1 & 22 & 21 & 20 & \multicolumn{2}{|l|}{04} & 67 \\
\hline Category 2 & 14 & 20 & 04 & \multicolumn{2}{|l|}{-} & 38 \\
\hline Category 3 & 07 & 03 & 11 & \multicolumn{2}{|l|}{03} & 24 \\
\hline Category 4 & 06 & 02 & 01 & \multicolumn{2}{|l|}{01} & 10 \\
\hline Total & 49 & 46 & 36 & \multicolumn{2}{|l|}{08} & 139 \\
\hline Photos & 03 & 18 & 07 & \multicolumn{2}{|l|}{-} & 28 \\
\hline \multicolumn{7}{|c|}{ Daily Jang Quetta May 2017} \\
\hline \multirow[t]{2}{*}{ Categories } & \multicolumn{4}{|c|}{ News Column } & \multirow{2}{*}{\multicolumn{2}{|c|}{ Total }} \\
\hline & $\begin{array}{l}1 \\
\text { colu } \\
\text { mn }\end{array}$ & $\begin{array}{l}2 \\
\text { colu } \\
\text { mn }\end{array}$ & $\begin{array}{l}3 \\
\text { colu } \\
\text { mn }\end{array}$ & $\begin{array}{l}4 \\
\text { colu } \\
\text { mn }\end{array}$ & & \\
\hline Category 1 & 16 & 43 & 30 & 05 & 94 & \\
\hline Category 2 & 05 & 32 & 09 & 01 & 47 & \\
\hline Category 3 & 20 & 10 & 09 & 01 & 40 & \\
\hline Category 4 & 21 & 09 & 06 & 0 & 36 & \\
\hline Total & 62 & 94 & 07 & 07 & 217 & \\
\hline Photos & 01 & 17 & 01 & - & 19 & \\
\hline
\end{tabular}




\begin{tabular}{|c|c|c|c|c|c|}
\hline \multicolumn{6}{|c|}{ Daily Express Intikhab Quetta May 2017} \\
\hline \multirow[t]{2}{*}{ Categories } & \multicolumn{4}{|c|}{ News Column } & \multirow[b]{2}{*}{ Total } \\
\hline & $\begin{array}{l}1 \\
\text { colu } \\
\text { mn }\end{array}$ & $\begin{array}{l}2 \\
\text { colu } \\
\text { mn }\end{array}$ & $\begin{array}{l}3 \\
\text { colu } \\
\text { mn }\end{array}$ & $\begin{array}{l}4 \\
\text { colu } \\
\text { mn }\end{array}$ & \\
\hline Category 1 & 16 & 36 & 39 & 08 & 99 \\
\hline Category 2 & 03 & 28 & 06 & - & 37 \\
\hline Category 3 & 18 & 21 & 09 & 09 & 57 \\
\hline Category 4 & 08 & 15 & 06 & 02 & 31 \\
\hline Total & 45 & 100 & 60 & 19 & 224 \\
\hline Photos & 05 & 32 & 07 & 01 & 45 \\
\hline
\end{tabular}

\section{Discussion}

It is pertinent to mention that all the selected newspapers have given coverage to the news related to Balochistan. The events occurred in Balochistan in the month of May 2017 are worth mentioning because the occurred events were of national and international scope. The suicide blast on Senate Deputy Chairman Maulana Ghafoor Haidri in the area of Mastung. At least 25 people were killed in the suicide blast. Since, Mr. Haidri is deputy Chairman of the Upper house of the country, it automatically gets the attention of National and International media. Pakistan Tehreek Insaf chairman's visit to Quetta city was another important event that was scheduled in the month of May, 2017. The two Chinese were abducted from Jinnah town, Quetta on 23rd May, 2017. This news was of international scope, especially in context of CPEC. The international media eyes were on the event and they were looking at this event very closely. Another unfortunate incident occurred in the Turbat 
city, where at least ten people laborers were killed. This news was of national scope and all the leading newspapers of the country have given coverage to this incident. The selected newspapers also have given coverage to these events and other news that were related to Balochistan. The political news were given high coverage by all the selected newspapers. A total of 67 news were given by Express Century, 94 news by Daily Jang and 99 news contents related to government were given by Daily Intikhab. Since, Daily Intikhab newspaper is owned by Anwar Sajidi belongs from Balochistan. The local inhabitants have better understanding of the political dynamics of Balochistan and they understand the importance of news coverage to the local news. The political news also get space in all the selected newspapers and Express Century have given 38 news contents related to Political beat, Daily Jang has given 47 news contents related to political beat. While, Daily Intikhab has given 37 news items related to Balochistan. News related crimes were also given coverage in all the three newspapers. Daily Express Century has given 24 news, Daily Jang has given 40 news and Daily Intikhab has given 57 news items related to crime. The above figures gives better idea that Daily Intikhab is giving proper and more coverage to the news items related to Balochistan. It may be due to the fact that it is run by Local inhabitants, who has better understanding of the regional political and administrative dynamics.

\section{Findings}

- The newspapers who have chain in other provinces are not giving proper coverage to Balochistan.

- The news related to government are given more coverage by all the selected newspapers. 
- The nationalist leaders are given less coverage by Daily Jang and Daily Express Century.

- Daily Intikhab is giving satisfactory coverage when it comes to pictures. A total of 57 photographs were published in month of May 2017.

- Daily Express Century Quetta has given a total of 139 news, Daily Jang Quetta has given 217 news and Daily Intikhab has given 224 news items related to Balochistan in one moth time.

\section{Recommendations}

- The newspapers needs to give proper and righteous coverage to Balochistan, as the national level newspapers are giving coverage to other provinces.

- Beside government news, the newspapers needs to give coverage to other beats as well.

- Since, the national level newspapers are published from other cities of the country as well, like Daily Jang and Daily Express Century are published from many cities, they should understand the fact if they publish Quetta edition, they must give maximum coverage to news related to Balochistan.

- The newspapers should give solution based news coverage to issues related to Balochistan.

- The newspapers should also follow code of conduct define for press by avoiding publishing photographs of crime scenes and victims. 


\section{Bibliography}

- Tahir,S.N.(2005). Balochistan mein Iblaghe-e-Aama Aghaz O Irtiqa 1888200. Islamabad: Academy of Letters

- Atarodi, A. (2011. Insurgency in Balochistan and why it is of strategic importance. Sweden: FOI, Swedish Defense Research Agency

- Grare, F. (2013). Balochistan- The state versus the nation, Frederic Grare

- Sarina Singh,B.L. (2008). Pakistan\& the Karakoram Highway. Lonely Planet Publishers.

- Support, I.M. (2016) . Voices of Wars: Conflict and the role of media

- Villa, Dana. R. (1992) Postmodernism and the Public sphere. American Political Science Review, Vo. 86, No.3.

- http://soschildrenvillages.org.uk/sos-childrencharity/child-soldiers.(2017, June 1) Retrieved fromhttp://www.soschildrensvillages.org.uk/soschildrencharity/child-soldiers.htm

- Wimmer D. Roger, Dominick R. Joseph. Mass media research An introduction, Thomas Wadsworth 